\title{
PREFERENSI PENONTON TERHADAP FILM INDONESIA
}

\author{
Muhammad Yaumul Rizky, Yolanda Stellarosa \\ STIKOM The London School of Public Relations - Jakarta \\ yaumulrizky@gmail.com,yolanda.s@lspr.edu
}

\begin{abstract}
This research aims to discover the preference of audiences towards Indonesian movie, located in Jakarta. The purpose of this study is to understand the audience preferences of Indonesia movie through movie attributes such as genre, symbolism, actor, director, sequel, production house, film set, and marketing. Quantitative descriptive research method was used in the research and questionnaire distributed to 200 respondents by applying purposive sampling technique. This research found that the most average of audience preferences from film attributes are: genre, marketing, sequel, symbolism, director, actor, film set and production house.
\end{abstract}

Keywords: Preference, Audience, Indonesian Movie, Quantitative, Uses and Gratification Theory, Film Attribute.

\begin{abstract}
ABSTRAK
Perkembangan perfilman Indonesia dari tahun ke tahun cenderung lambat. Dikabarkan juga bahwa perfilman Indonesia akan redup. Namun saat ini perfilman Indonesia justru semakin berkembang dan mulai diminati. Penelitian ini dilakukan untuk mengetahui tentang preferensi penonton terhadap film Indonesia di Jakarta dilihat dari atribut film seperti genre, karya saduran, pemain, sutradara, sekuel, rumah produksi, latar, dan pemasaran. Penelitian ini menggunakan metode penelitian kuantitatif deskriptif, kuesioner dibagikan kepada 200 orang responden dengan teknik purposive sampling. Hasil penelitian menunjukkan bahwa preferensi penonton terhadap film Indonesia cenderung pada atribut film genre film, preferensi kedua adalah pemasaran, preferensi ketiga adalah sekuel, preferensi keempat adalah karya saduran, preferensi kelima adalah sutradara, preferensi keenam adalah pemain, preferensi ketujuh adalah latar dan preferensi terakhir adalah rumah produksi.
\end{abstract}

Kata kunci: Preferensi, Penonton, Film Indonesia, Kuantitatif, Teori Uses and Gratification, Atribut Film. 


\section{PENDAHULUAN}

Preferensi adalah kesukaan. Kebutuhan individu yang tidak sama atau beragam membuat daya kepuasan setiap individu juga berbeda. Pemenuhan dan pemuasan kebutuhan penonton dalam media adalah untuk mendapatkan hiburan, informasi, pendidikan dan budaya (McQuail, 2011).

Preferensi individu yang beragam dalam pemuasan kebutuhan tersebut dapat disadari seperti individu yang mencari hiburan dalam mengalihkan masalah keseharian, kesibukannya dan rutinitasnya, misalnya saja dengan menonton film. Pemuasan individu juga bisa di pengaruhi melalui faktor lingkungannya. Seperti seorang individu yang sedang menuntut ilmu di dunia perfilman maka akan mencari referensi film dengan menonton segala jenis film agar mendapatkan pengalaman dan pemahaman baru untuk dipraktekannya ke dalam dunia karir perfilmannya tersebut.

Sineas film menjadikan preferensi penonton sebagai acuan dalam mengikuti pangsa pasar dalam pembuatan film. Acuan tersebut dilihat dengan memahami fungsi umum dalam suatu film yaitu sebagai pencerminan nilai-nilai sosial budaya, pendidikan, hiburan, dan informasi pada masyarakat di suatu bangsa. Seperti yang dikatakan Amura, 1989, bahwa film bukan semata-mata barang dagangan melainkan alat penerangan dan pendidikan. Film merupakan karya sinematografi yang dapat berfungsi sebagai alat pendidikan budaya. Dengan demikian film juga efektif untuk menyampaikan nilai-nilai budaya (Trianton, 2013).

Pilihan dan perbedaan penonton merupakan pengaruh kuat dalam persaingan media, terutama media audio dan visual. Persaingan tersebut ditinjau dalam hal pemilihan, perhatian, dan penggunaan untuk memuaskan kebutuhan dan keinginan penonton. Penonton memiliki latar belakang dalam memilih media berdasarkan preferensi, motif dan adanya ketertarikan yang muncul dalam diri sendiri. Latar belakang tersebut sebagai pondasi utama atau garis awal individu dalam memilih media. Latar belakang audien ini dipandang sebagai partisipan yang aktif dalam menentukan penggunaan media. Media merupakan suatu penghubung dalam mengapresiasikan kreasi dan budaya.

Seluruh fungsi umum dalam film bisa diidentifikasi dengan memahami atribut yang ada didalam film. Terdapat dua atribut film yaitu naratif dan sinematik. Naratif terdiri dari cerita dan plot, ruang dan waktu. Sebuah film akan menarik untuk ditonton ketika memiliki cerita dan plot serta ruang dan waktu yang jelas dan dapat dipahami oleh penonton. Oleh karena itu naratif adalah fondasi utama sineas dalam menciptakan sebuah film. Sedangkan atribut film berdasarkan sinematik terdiri dari sinematografi, editing, dan mise en scene. Sinematik adalah proses untuk mewujudkan naratif yang sudah dibuat oleh sineas ke dalam bentuk audio dan visual. Sinematik merupakan ujung tombak suatu film ketika film telah ditayangkan di depan penonton atau penikmat film. 
Kedua atribut film saling berketerkaitan dan berkesinambungan dalam membentuk sebuah peristiwa dengan maksud dan tujuan. Peristiwa yang mengikat ini disebut sebagai hukum kausalitas atau logika sebab dan akibat (Pratista, 2008).

Keinginan penonton dalam mencari, menggunakan dan menilai suatu film telah membuat dunia perfilman saat ini menjadi sorotan utama sineas dalam menyalurkan hobi, minat, bakat, dan usaha mereka di Indonesia. Film Indonesia mulai bangkit kembali pasca gerakan reformasi tahun 1998. Berawal dari menurunnya semangat dalam produksi film Indonesia pada pertengahan tahun 90-an. Penurunan ini terjadi dipengaruhi oleh berbagai macam faktor, faktor pertama adalah perkembangan bioskop di Indonesia yang mulai berkelas-kelas hingga peraturan pemerintah yang sangat ketat atas pemutaran perfilman pada masa Orde baru. Bioskop yang berkelas dimulai pada nama Cinemascope yang mulai dikenal dengan Bioskop 21. Kehadiran bioskop 21 mulai menggeser peredaran flm-film lokal yang ditayangkan pada bioskop-bioskop kecil atau pinggiran. Faktor kedua adalah tema film yang monoton dan cenderung diproduksi untuk mendapat keuntungan tanpa mempertimbangkan kualitas film tersebut.

Faktor ketiga adalah dikarenakan impor dan distribusi film yang diserahkan kepada pihak swasta. Seperti bioskop di Indonesia lebih banyak memutarkan film-film produksi Hollywood saja dan sedikit memutarkan film Indonesia. Faktor keempat adalah ketika diawal tahun 90-an hadir dan maraknya stasiun-stasiun televisi swasta yang menghadikan film-film impor dan sinema elektronik serta telenovela.

Faktor kelima adalah ketika memasuki pemerintahan Orde Baru juga membuat penayangan film Indonesia semakin merosot oleh prosedur penyensoran film yang cukup kompleks dengan isu penyensoran dikaitkan aspek politik, ekonomi, sosial budaya, agama, bahkan hak asasi manusia. Penggunaan film pada masa ini juga terhubung campur tangan oleh pemegang kekuasaan yang menggunakan film sebagai media propaganda. Faktor keenam adalah krisis moneter yang terjadi pada masa ini juga menyusutkan penayangan film Indonesia yang harus bersaing ketat dengan film impor (Awaluddin, 2012).

Keenam faktor tersebut menyebabkan peningkatan produksi film Indonesia baik melalui komunitas, festival, pendidikan dan melalui jalur industri tidak sebanding lurus dengan jumlah penonton di Indonesia. Masih lebih banyak jumlah penonton yang menonton film luar dibandingkan film Indonesia (Awaluddin, 2012).

Untuk membangkitkan film Indonesia dari keterpurukannya diperlukan daya tarik tertentu yang menjadi pendorong orang untuk datang ke bioskop dan menonton film. Banyak faktor daya tarik yang bisa menyebabkan penurunan jumlah penonton film. Baik dari segi promosi, kuota penayangan, pemeran film, isu yang diangkat dalam film, waktu peredaran film, pembuat film, bahkan hingga kualitas film. Menurut Ketua Gabungan Pengusaha Bioskop Indonesia, Djonny Syafruddin mengungkapkan data statistik 
menunjukkan bahwa anjloknya jumlah penonton umumnya bukan karena tidak diberikan kesempatan tayang di bioskop, melainkan karena film itu sendiri memang tidak bermutu (Rulianto, 2015).

Berdasarkan data yang diambil dari Badan Perfilman Indonesia melalui akun twitter resmi @BadanPerfilman, akumulasi data terkini jumlah penonton film Indonesia sampai dengan 21 Desember 2015 dari Cinema21, CGV Blitz dan Cinemaxx adalah peringkat pertama diduduki film berjudul Single dengan jumlah penonton sebanyak 331.844 ribu. Peringkat kedua diduduki Bulan Terbelah di Langit Amerika dengan jumlah penonton sebanyak 264.727 ribu. Peringkat ketiga film berjudul Villa 603 mendapatkan jumlah penonton sebanyak 116.059 ribu. Namun melihat data yang diambil dari website FilmIndonesia.or.id baru terdapat dua film yang mencapai satu juta penonton dilihat melalui perolehan jumlah penonton tahun 2015 berdasarkan tahun edar film, yaitu film Surga yang Tak Dirindukan dan Comic 8: Kasino Kings part 1 (Data Penonton, 2015). Kedua film tersebut merupakan film yang berakhir edar pada bulan Oktober 2015. Dari hasil kedua data tersebut dapat disimpulkan bahwa minat masyarakat dalam menonton film Indonesia belum besar dan seharusnya pada hari libur nasional merupakan kesempatan bagi masyarakat untuk menonton bioskop.

Bila dibandingkan dengan data jumlah penonton film yang dilihat pada tahun edar film 2014 dengan 2015, jumlah penonton yang mencapai 1 juta hanya dua film, yaitu peringkat pertama merupakan prekuel Casino 8: Kasino Kings Part 1 yaitu Casino 8, peringkat kedua adalah film The Raid 2: Berandal. Namun penurunan jumlah penonton dari tahun 2014 - 2015 dapat dilihat dari jumlah tertinggi dan terendah data penonton dari tahun 2014 - 2015. Penonton tertinggi pada tahun 2014 sebanyak 1.624 .067 penonton, sedangkan penonton tertinggi pada tahun 2015 sebanyak 1.523 .570 penonton. Lalu penonton terendah pada tahun 2014 sebanyak 375.799 penonton, sedangkan penonton terendah pada tahun 2015 sebanyak 273.581 penonton (Data Penonton, 2014).

Penjelasan di atas menunjukan bahwa minat penonton di Indonesia dapat dikatakan masih fluktuatif. Maka berdasarkan latar belakang di atas penelitian ini ingin bertujuan mengetahui bagaimana preferensi penonton pada film Indonesia dilihat dari dimensi atribut film. Sehingga dunia perfilman di Indonesia bisa berkembang, mendapatkan apresiasi, dan bersaing dengan film luar yang tayang di Indonesia.

\section{TINJAUAN PUSTAKA}

\section{Preferensi Penonton}

Preferensi adalah kesukaan (McQuail, 2011). Sedangkan khalayak (Audience) adalah seluruh bagian lapisan pembaca, pendengar, dan penonton yang menerima konten media 
atau merupakan target dari penyiaran media (McQuail, 2011). Tanpa adanya khalayak tidak ada komunikasi massa, dan khalayak memiliki peranan dinamis dalam membentuk aliran dan efek media. Khalayak dapat juga dikatakan sebagai konsumen media.

Maka dapat dipahami bahwa preferensi khalayak atau penonton adalah kesukaan, pilihan atau kecenderungan penonton dalam menentukan satu kebutuhan dari menonton film. Dalam penelitian ini preferensi penonton mengarah kepada film Indonesia sebagai kebutuhan dari menonton film.

Besarnya jumlah khalayak yang dapat diperoleh merupakan penentu keberhasilan suatu media. McQuail (2011) menyatakan karakteristik penonton sebagai berikut: 1) penonton merupakan kumpulan konsumen baik yang nyata maupun yang potensial; 2) anggota penonton tidak saling berkaitan satu sama lain dan tidak memiliki identitas diri bersama; 3) batasan yang ditentukan kepada khalayak umumnya berdasarkan kriteria sosialekonomi; 4) penonton adalah objek pengaturan dan kontrol oleh media; 5) pembentukannya bersifat sementara; 6) kepentingan publik adalah sesuatu yang dinomorduakan dan 7) hubungan penonton dengan media adalah saling perhitungan dan bukan berdasarkan moral.

Dari penjelasan di atas dapat dipahami bahwa penonton dapat menentukan keberhasilan suatu produk media. Namun keberhasilan suatu produk media yang dilihat dari besarnya jumlah penonton belum tentu menentukan kualitas produk medianya.

Berkaitan dengan preferensi penonton terdapat beberapa penelitian sebelumnya yang dijadikan acuan dalam penelitian ini. Penelitian pertama yang dijadikan acuan adalah penelitian yang dilakukan oleh Ita Kurniawati (2006) berjudul Preferensi Pembaca Terhadap Rubrik Surat Kabar Jawa Pos (Studi pada Pembaca Jawa Pos di Malang Melalui Metode Item selection dan Tracking study). Dengan memahami rubrik yang disajikan dalam surat kabar mulai dari informasi hiburan, pendidikan, hingga informasi politik dapat memahami pembaca apakah mereka memperoleh informasi atau berita sesuai kebutuhannya. Namun kebutuhan setiap pembaca yang beragam dan selektif membuat pembaca memiliki kecenderungan yang berbeda-beda dalam mengkonsumsi berita. Penelitian ini ingin mengetahui pilihan rubrik serta bagaimana cara responden membaca topik dari rubrik yang pertama dibaca.

Penelitian kedua yang dijadikan acuan berjudul Perbedaan Preferensi Konsumen Terhadap Atribut Film oleh Deavy Rosaline Henny Klavert (2013). Penelitian ini bertujuan untuk memahami segala perbedaan preferensi konsumen terhadap atribut film dilihat dari gender, umur, dan pekerjaan. Varibel yang digunakan adalah genre, cast, direktur, simbol, negara asal, rumah produksi, dan sekuel, berserta variabel pendukung yaitu bahan informasi dan teknologi. Metode yang digunakan adalah survei dengan 200 responden yang menonton film. 
Perbedaan dalam penelitian sebelumnya dengan penelitian "Preferensi Penonton terhadap Film Indonesia" adalah penggantian sebuah variabel dengan variabel yang dianggap memengaruhi penonton dalam menonton film dan berhubungan dengan atribut film, yaitu variabel pemasaran. Adapun menghilangkan efek penggunaan Country of Origin yang membuat penelitian ini bias terhadap persepsi penonton Indonesia tentang lokasi produksi dan rumah produksi dari sebuah film yang menyebabkan adanya penjelasan lebih terperinci.

\section{Film}

Pengertian film dapat beragam karena tergantung pemahaman melalui sudut pandang orang yang mendefinisikannya. Film didefinisikan sebagai penyambung materi fisik, berakhir dalam sebuah gulungan hitam bergambar yang tidak bergerak (Frampton, 2009).

Pasal 1 UU No. 23 Tahun 2009 tentang Perfilman menyebutkan bahwa film adalah karya seni budaya yang merupakan pranata sosial dan media komunikasi massa yang dibuat berdasarkan kaidah sinematografi dengan atau tanpa suara dan dapat dipertunjukkan. Ada juga pengertian film sebagai media komunal, yaitu perpaduan dari berbagai teknologi dan unsur-unsur kesenian baik seni rupa, teater, sastra, arsitektur, dan musik atau perpaduan dari perkembangan teknologi fotografi dan rekaman suara (Trianton, 2013).

Terdapat dua aspek utama pembentuk film yang saling berhubungan erat satu sama lain, yaitu unsur naratif dan unsur sinematik. Namun dalam penelitian sebelumnya, atribut film yang dapat mempengaruhi preferensi dalam menonton film pada umumnya diketahui oleh penonton seperti genre, symbolism, country of origin, pemain, sutradara, sekuel, dan rumah produksi (Gazley, Clark, \& Sinha, 2011). Dalam penelitian ini atribut film yang akan digunakan adalah genre, karya saduran, pemain, sutradara, rumah produksi, sekuel, latar dan pemasaran. Country of origin tidak lagi digunakan dalam penelitian ini karena atribut tersebut menjelaskan bahwa film dari beberapa negara memiliki gaya atau narasi yang khas sehingga menjadi lebih atau kurang atraktif bagi konsumen. Sedangkan penelitian ini hanya memfokuskan penelitian kepada film Indonesia. Namun terdapat penambahan atribut dengan latar dan pemasaran sebagai penguat penelitian ini.

Genre dalam film dapat didefinisikan sebagai jenis atau klasifikasi dari sekelompok film yang memiliki karakter atau pola sama seperti setting, isi dan subjek cerita, tema, struktur cerita, aksi atau peristiwa, periode, gaya, situasi, ikon, mood, serta karakter. Klasifikasi tersebut menghasilkan genre-genre populer seperti aksi, petualangan, drama, komedi, horror, western, thriller, film noir, roman, dan sebagainya (Pratista, p. 10). 
Genre berfungsi untuk memudahkan klasifikasi sebuah film dan membagikan film dari seluruh film-film yang pernah diproduksi. Selain berfungsi sebagai mengklasifikan film, genre berfungsi untuk memberikan gambaran umum kepada penonton terhadap film yang akan mereka saksikan.

Pengertian dari aspek symbolism atau karya saduran adalah hubungan dengan karyakarya sebelumnya. Misalnya novel yang diadaptasi dalam sebuah film, drama, serial televisi, atau permainan computer (Hennig-Thurau). Film-film dengan bersifat adapted screenplay memiliki kepastian lebih besar di pasar daripada film-film original screenplay karena penonton sudah memiliki pre-existing awareness tentang sebuah film (Gazley C. S., 2011).

Pelaku cerita atau pemain adalah individu yang diciptakan atau rekaan pengarang yang mengalami peristiwa-peristiwa yang ada dalam cerita. Pelaku cerita akan memotivasi naratif dan selalu bergerak dalam melakukan sebuah aksi. Pelaku cerita dapat memiliki wujud fisik yang beragam dan tidak selalu berwujud manusia. Adapun pelaku cerita juga dapat dikelompokkan menjadi beberapa jenis sesuai tuntutan dan fungsinya dalam sebuah film. Performa seorang pelaku cerita adalah sebuah kunci utama keberhasilan suatu film (Pratista, 2008).

Direktur atau sutradara adalah salah satu orang yang berada di balik layar yang dianggap sebagai seorang yang memiliki daya tarik sendiri bagi konsumen. Sutradara bertugas dalam menjawab produser dan bertanggung jawab untuk detail dan kualitas film. Hal ini memerlukan kemampuan sutradara dalam memvisikan film dengan penulis skrip dan produser, merekrut, mengawasi, mengarahkan aktor dan kru (lapangan, editing, dan promosi) agar tercipta film berkualitas dan penjualan yang baik. (Rabiger, 2008).

Rumah produksi film adalah suatu organisasi atau wadah untuk menampung minat dan bakat dalam dunia film dan televisi. Dalam melakukan kegiatan ini, rumah produksi menyediakan peralatan dan lokasi untuk mencari atau mendapatkan keuntungan dari kegiatan tersebut.

Sekuel adalah karya dalam sastra, film, atau media lain yang meneruskan, mengembangkan, dan menambahkan beberapa unsur untuk melengkapi cerita sebelumnya.

Pemasaran adalah kegiatan proses sosial dan manajerial yang darinya individu dan kelompok memperoleh apa yang mereka butuhkan dan inginkan melalui penciptaan dan pertukaran produk serta nilai dengan pihak lain. Oleh karena itu, pemasaran dalam perfilman adalah kegiatan penjualan dan periklanan yang dilakukan oleh produser dan sutradara dalam meningkatkan kesadaran penonton terhadap produk filmnya dengan materi pemasaran film seperti teaser trailer, official trailer, penjualan karya sebelumnya, penjualan sebuah produk, soundtrack, dan lain-lain. (Kotler \& Amstrong, 2003). Peneliti 
mempertimbangkan pemasaran sebagai salah satu atribut dalam film untuk penelitian "Preferensi penonton terhadap film Indonesia." Hal ini berhubungan dengan tahap PostProduction dalam sebuah film.

Latar merupakah keseluruhan lokasi dan tempat bersama segala propertinya. Properti yang dimaksud adalah semua benda tidak bergerak seperti perabotan, pintu, jendela, dan sebagainya. Latar harus mampu meyakinkan penonton dengan latar yang otentik atau sama persis sesuai dengan konteks lokasi dan waktu cerita dalam film. Latar memberikan informasi yang kuat dalam mendukung cerita film sebagai petunjuk ruang dan waktu. Shot on location atau produksi film sesuai dengan lokasi sesungguhnya sudah populer sejak sinema Neoralisme Italia dan New Wave Perancis (Pratista, 2008).

Penelitian ini menggunakan latar dengan metode shot on location sebagai atribut karena mulai banyak film Indonesia yang berlokasi syuting di luar negeri, seperti "Negeri Van Oranje", "Assalamualaikum Beijing", atau alam terbuka seperti "5 Cm" yang berlokasi di Gunung Semeru.

Dalam penelitian ini atribut country of origin digantikan oleh atribut pemasaran. Karena country of origin menjelaskan tentang negara asal pembuatan film dilakukan, sedangkan penelitian ini memfokuskan pada perfilman Indonesia (Gazley, 2011).

\section{METODE PENELITIAN}

Metode yang digunakan dalam penelitian ini adalah kuantitatif deskriptif untuk melihat preferensi penonton terhadap film Indonesia. Untuk dapat menjelaskan permasalahan penelitian yang ada, maka pendekatan kuantitatif dirasa cocok untuk digunakan. Sedangkan deskriptif digunakan untuk meneliti perilaku yang sedang terjadi dan terdiri dari satu variabel.

Responden dalam penelitian ini adalah penonton film yang menonton film Indonesia, berusia 17-30 tahun dan berlokasi di Jakarta. Penentuan responden atau sampel menggunakan tehnik non probability sampling dan purposive sampling, berjumlah sebanyak 200 orang di Jakarta. Ukuran sampel yang layak dalam penelitian menurut Roscoe (1982) adalah antara 30 sampai dengan 500 orang (Sugiyono, 2009).

Data primer diperoleh melalui penyebaran kuesioner pertanyaan berstruktur dengan beberapa pilihan jawaban yang ada dan menggunakan skala Likert sebagai skala pengukuran. Penyebaran kuesioner dilakukan melalui internet atau instant message seperti line messenger dan whatsapp kepada responden. Setelah data terkumpul, maka analisis data yang digunakan adalah analisis data univariat, yaitu analisis yang dilakukan 
untuk penelitian yang hanya menggunakan satu variabel. Dalam analisis univariat ini, data hasil penelitian diolah dan disajikan dalam tabel frekuensi.

\section{Operasionalisasi Konsep}

Variabel dalam penelitian ini terbagi dalam 8 dimensi preferensi penonton terbadap film Indonesia yang dilihat dari atribut film, yaitu 1) genre, 2) symbolism, 3) pemain, 4) sutradara, 5) rumah produksi, 6) sekuel, 7) pemasaran dan 8) latar atau lokasi cerita.

Tabel 1

Operasionalisasi Variabel

\begin{tabular}{|c|c|c|c|}
\hline Variabel & Dimensi & Indikator & Skala \\
\hline $\begin{array}{l}\text { Preferensi } \\
\text { Penonton } \\
\text { Film Indonesia }\end{array}$ & $\begin{array}{l}\text { Genre } \\
\text { Simbolisme } \\
\text { Pemain } \\
\text { Sutradara } \\
\text { Rumah } \\
\text { Produksi } \\
\text { Sekuel } \\
\text { Pemasaran } \\
\text { Latar }\end{array}$ & $\begin{array}{l}\text { Genre horror, comedy, action, drama, dan } \\
\text { lain-lain } \\
\text { Karya saduran seperti Novel, Game, Komik, } \\
\text { Kartun, dan lain-lain } \\
\text { 1. Kehadiran } \\
\text { 2. Kredibilitas } \\
\text { 3. Reputasi } \\
\text { 1. Kredibilitas } \\
\text { 2. Reputasi } \\
\text { 3. Selera } \\
\text { 1. Kredibilitas } \\
\text { 2. Kualitas } \\
\text { 3. Karya } \\
\text { Karya lanjutan } \\
\text { Materi pemasaran: poster, trailer, publikasi } \\
\text { Lokasi cerita }\end{array}$ & Likert \\
\hline
\end{tabular}

Sumber: Pratista, 2008 


\section{HASIL DAN PEMBAHASAN}

\section{Karakteristik Responden}

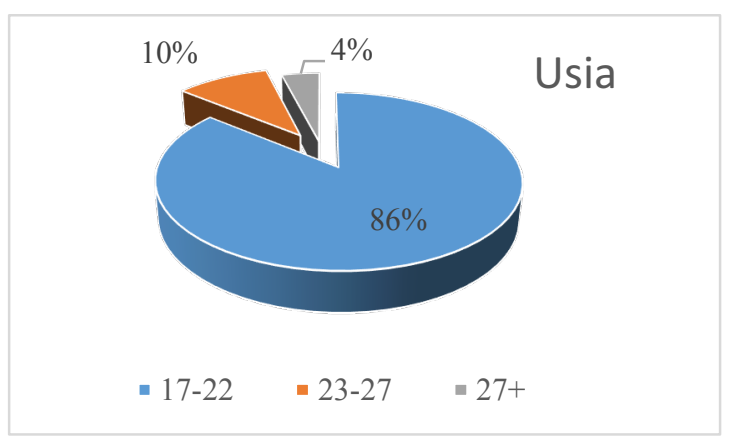

Gambar 1. Usia

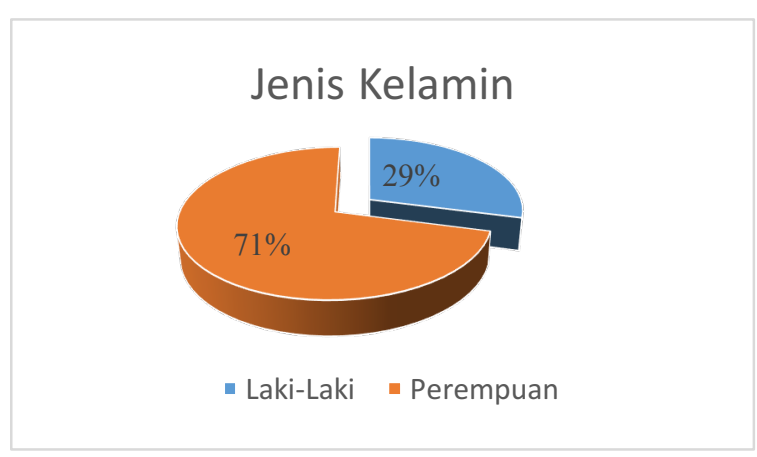

Gambar 2. Jenis Kelamin

Berdasarkan gambar di atas jenis kelamin responden pada penelitian ini mayoritas adalah perempuan, yaitu sebesar 71\%. Sedangkan responden laki-laki hanya berjumlah 29\%. Tidak ada ketetapan jumlah responden untuk kategori jenis kelamin sehingga siapa saja berhak menjadi responden menurut kriteria yang ditentukan. Usia 17-22 tahun mendominasi responden yang juga penonton film Indonesia, yaitu sebesar 86\%. Berdasarkan intensitas menonton dalam sebulan terakhir, mayoritas responden berada pada kisaran 1 kali menonton film dalam satu bulan, yaitu sebesar 69\%. Sedangkan $17,5 \%$ responden menonton 2 kali dalam sebulan.

\section{Dimensi Genre}

Dimensi genre dalam penelitian ini terbagi atas beberapa pertanyaan yang menyangkut mengenai gambaran genre film yang ditonton.

Tabel 2

Pertanyaan dalam Dimensi Genre

\begin{tabular}{|c|c|c|c|c|c|}
\hline \multicolumn{1}{|c|}{ Item Pertanyaan } & SS & S & RR & TS & STS \\
\hline $\begin{array}{l}\text { Genre horor, komedi, action, drama } \\
\text { dan lainnya memberikan gambaran } \\
\text { umum film yang ditonton }\end{array}$ & $21 \%$ & $68 \%$ & $8,5 \%$ & $2 \%$ & $0.5 \%$ \\
\hline $\begin{array}{l}\text { Genre horor, komedi, action, drama } \\
\text { dan lainnya membantu dalam } \\
\text { memilih film yang ditonton }\end{array}$ & $25 \%$ & $66 \%$ & $5,5 \%$ & $3,5 \%$ & $0 \%$ \\
\hline $\begin{array}{l}\text { Genre horor, komedi, action, drama } \\
\text { dan lainnya memberikan } \\
\text { ekspektasi lebih terhadap film yang } \\
\text { ditonton }\end{array}$ & $20 \%$ & $59,5 \%$ & $10 \%$ & $9,5 \%$ & $1 \%$ \\
\hline $\begin{array}{l}\text { Menonton film berdasarkan genre } \\
\text { yang disukai }\end{array}$ & $26,5 \%$ & $59,5 \%$ & $8 \%$ & $6 \%$ & $0 \%$ \\
\hline
\end{tabular}


Dari tabel di atas dapat dilihat bahwa mayoritas responden setuju dan sangat setuju sebesar 89\% bahwa genre suatu film seperti horor, komedi, aksi drama dan lainnya dapat memberikan gambaran umum film yang ditonton. Selain itu genre juga membantu dalam memilih film yang ditonton yaitu sebesar 91\%. Genre sebuah film juga memberikan ekspektasi dan harapan lebih akan film yang ditonton, sebesar 79,5\%. Dalam menonton film, responden mayoritas menyatakan setuju dan sangat setuju yaitu sebesar 86\% bahwa mereka menonton film berdasarkan genre yang disukai.

\section{Dimensi Karya Saduran}

Tabel 3

Pertanyaan dalam Dimensi Karya Saduran

\begin{tabular}{|l|l|l|l|l|l|}
\hline \multicolumn{1}{|c|}{ Item Pertanyaan } & SS & S & RR & TS & STS \\
\hline $\begin{array}{l}\text { Karya saduran seperti novel, game, } \\
\text { komik, kartun dan lainnya } \\
\text { memberikan gambaran akan film } \\
\text { yang disaksikan }\end{array}$ & $20,5 \%$ & $63,5 \%$ & $12,5 \%$ & $3,5 \%$ & $0 \%$ \\
\hline $\begin{array}{l}\text { Karya saduran seperti novel, game, } \\
\text { komik, kartun dan lainnya } \\
\text { memudahkan dalam memahami film } \\
\text { yang ditonton }\end{array}$ & $17 \%$ & $58 \%$ & $16 \%$ & $9 \%$ & $0 \%$ \\
\hline $\begin{array}{l}\text { Karya saduran seperti novel, game, } \\
\text { komik, kartun dan lainnya } \\
\text { membantu dalam memilih film yang } \\
\text { ditonton }\end{array}$ & $17,5 \%$ & $61,5 \%$ & $13 \%$ & $8 \%$ & $0 \%$ \\
\hline
\end{tabular}

Dari tabel di atas mayoritas responden menyatakan setuju dan sangat setuju bahwa karya saduran suatu film dapat memberikan gambaran tentang film yang ditonton atau disaksikannya, yaitu sebesar 84\%. Karya saduran yang dimaksud di sini misalnya film "Sabtu Bersama Bapak" (2016) yang diangkat dari novel berjudul sama. Akan tetapi terdapat $12.5 \%$ reponden yang menyatakan ragu-ragu dan $3.5 \%$ responden menyatakan tidak setuju.

Karya saduran suatu film juga dapat membuat penonton mudah untuk memahami film yang disaksikannya, yaitu sebesar 75\%. Misalnya saja saat menonton film "Koala Kumal" (2016) yang disadur dari novel berjudul sama karya Raditya Dika. Namun, terdapat 16\% responden yang menyatakan ragu-ragu dan 9\% yang menyatakan tidak setuju. Karya saduran ternyata juga dapat membantu responden dalam memilih film yang ingin 
ditontonnya. Mayoritas responden menjawab setuju dan sangat setuju, yaitu sebesar $79 \%$.

\section{Dimensi Pemain}

Tabel 4

Pertanyaan dalam Dimensi Pemain

\begin{tabular}{|l|l|l|l|l|l|}
\hline \multicolumn{1}{|c|}{ Item Pertanyaan } & SS & S & RR & TS & STS \\
\hline $\begin{array}{l}\text { Pemain seperti Dian Sastro, Iko } \\
\text { Uwais, Raditya Dika dan lainnya } \\
\text { dapat anda pahami perannya } \\
\text { dengan baik }\end{array}$ & $20 \%$ & $64,5 \%$ & $11,5 \%$ & $4 \%$ & $0 \%$ \\
\hline $\begin{array}{l}\text { Pemain seperti Dian Sastro, Iko } \\
\text { Uwais, Raditya Dika dan lainnya } \\
\text { membuat anda memiliki ekspektasi } \\
\text { lebih terhadap film yang } \\
\text { diperankannya }\end{array}$ & $23 \%$ & $63 \%$ & $6,5 \%$ & $7 \%$ & $0,5 \%$ \\
\hline $\begin{array}{l}\text { Pemain seperti Dian Sastro, Iko } \\
\text { Uwais, Raditya Dika dan lainnya } \\
\text { menjadi penentu dalam memilih } \\
\text { film yang ditonton }\end{array}$ & $20 \%$ & $61,5 \%$ & $10 \%$ & $7 \%$ & $1,5 \%$ \\
\hline $\begin{array}{l}\text { Reputasi pemain menentukan anda } \\
\text { dalam memilih film yang ditonton }\end{array}$ & $14,5 \%$ & $51,5 \%$ & $14 \%$ & $16 \%$ & $4 \%$ \\
\hline
\end{tabular}

Berdasarkan tabel di atas mayoritas responden menyatakan setuju dan sangat setuju bahwa pemain atau aktor/aktris terkenal seperti Dian Sastro, Iko Uwais, Raditya Dika dan lainnya dapat dipahami perannya dengan baik, yaitu sebesar 84,5\%. Akan tetapi terdapat $11,5 \%$ responden yang menyatakan ragu-ragu dan $4 \%$ yang menyatakan tidak setuju. Selain itu mayoritas responden sebesar $86 \%$, menyatakan bahwa pemain seperti Reza Rahadian, Dian Sastro, Raditya Dika, dan lain-lain membuat penonton memiliki ekspektasi lebih terhadap film yang ditontonnya. Misalnya saja film Rudy Habibie (2016) yang dibintangi oleh Reza Rahadian, penonton akan berekspektasi bahwa dengan adanya Reza Rahadian dalam film tersebut dapat memuaskan mereka. Akan tetapi terdapat 6.5\% reponden yang menyatakan ragu-ragu dan $7.5 \%$ responden menyatakan tidak setuju dan sangat tidak setuju.

Pemain dan reputasinya juga menjadi penentu responden memilih film yang ditontonnya. Mayoritas responden yang menyatakan pemain jadi penentu film yang 
ditonton yaitu sebesar $81,5 \%$. Sedangkan yang berkaitan dengan reputasi penonton sebesar $66 \%$.

\section{Dimensi Sutradara}

Tabel 5

Pertanyaan dalam Dimensi Sutradara

\begin{tabular}{|l|l|l|l|l|l|}
\hline \multicolumn{1}{|c|}{ Item Pertanyaan } & SS & S & RR & TS & STS \\
\hline $\begin{array}{l}\text { Sutradara seperti Mira Lesmana, } \\
\text { Joko Anwar, Hanung Bramantyo dan } \\
\text { lainnya menentukan dalam memilih } \\
\text { film yang ditonton }\end{array}$ & $16 \%$ & $61,5 \%$ & $13,5 \%$ & $8 \%$ & $1 \%$ \\
\hline $\begin{array}{l}\text { Kredibilitas sutradara seperti Mira } \\
\text { Lesmana, Joko Anwar, Hanung } \\
\text { Bramantyo dan lainnya memberikan } \\
\text { ekspektasi lebih akan film yang } \\
\text { ditonton }\end{array}$ & $22 \%$ & $60 \%$ & $12 \%$ & $5 \%$ & $1 \%$ \\
\hline $\begin{array}{l}\text { Sutradara seperti Mira Lesmana, } \\
\text { Joko Anwar, Hanung Bramantyo dan } \\
\text { lainnya membuat anda dapat } \\
\text { langsung melihat gambaran genre } \\
\text { film yang diproduksinya }\end{array}$ & $9 \%, 6 \%$ & $17 \%$ & $7 \%$ & $1,5 \%$ \\
\hline
\end{tabular}

Berdasarkan tabel di atas mayoritas responden menyatakan setuju dan sangat setuju yaitu sebesar 77.5\%, bahwa sutradara seperti Joko Anwar, Mira Lesmana, Hanung Bramantyo dan lain-lain menentukan responden dalam memilih film yang akan disaksikan. Akan tetapi terdapat $13.5 \%$ reponden yang menyatakan ragu-ragu dan $9 \%$ responden menyatakan tidak setuju dan sangat tidak setuju.

Selain itu mayoritas responden menyatakan bahwa kredibilitas sutradara juga memberikan ekspektasi lebih akan film yang ditonton, yaitu sebesar 82\%. Akan tetapi terdapat $12 \%$ reponden yang menyatakan ragu-ragu dan $7 \%$ responden menyatakan tidak setuju dan sangat tidak setuju. Sutradara tertentu seperti Mira Lesmana, Joko Anwar, Hanung Bramantyo, Rizal Mantovani juga membuat responden dapat langsung mendapat gambaran mengenai genre film yang diproduksinya, yaitu sebesar $74,5 \%$. 


\section{Dimensi Rumah Produksi}

Tabel 6

Pertanyaan dalam Dimensi Rumah Produksi

\begin{tabular}{|l|l|l|l|l|l|}
\hline \multicolumn{1}{|c|}{ Item Pertanyaan } & SS & S & RR & TS & STS \\
\hline $\begin{array}{l}\text { Rumah produksi tertentu } \\
\text { menentukan dalam memilih film yang } \\
\text { ditonton }\end{array}$ & $5 \%$ & $40 \%$ & $26 \%$ & $26 \%$ & $3 \%$ \\
\hline $\begin{array}{l}\text { Kredibilitas rumah produksi } \\
\text { memberikan ekspektasi lebih akan } \\
\text { film yang ditonton }\end{array}$ & $4 \%$ & $44,5 \%$ & $24,5 \%$ & $23 \%$ & $4 \%$ \\
\hline $\begin{array}{l}\text { Rumah produksi tertentu dapat } \\
\text { langsung memberikan gambaran akan } \\
\text { karya film yang ditonton }\end{array}$ & $3 \%$ & $38 \%$ & $29 \%$ & $26 \%$ & $14 \%$ \\
\hline
\end{tabular}

Berdasarkan tabel di atas responden menyatakan setuju dan sangat setuju yaitu 45\%, bahwa rumah produksi seperti Multivision, Soraya Films, dan lain-lain mempengaruhi penonton dalam menentukan film yang ditonton. Akan tetapi terdapat $26 \%$ reponden yang menyatakan ragu-ragu dan $29 \%$ responden menyatakan tidak setuju dan sangat tidak setuju. Sedangkan untuk melihat apakah kredibilitas rumah produksi dapat memunculkan ekspektasi tertentu akan film yang ditonton, mayoritas responden menyatakan setuju dan sangat setuju yaitu sebesar 48,5\%. Akan tetapi terdapat $24 \%$ yang menyatakan ragu-ragu dan $27 \%$ yang menyatakan tidak setuju.

Berkaitan dengan apakah rumah produksi tertentu dapat langsung memberikan gambaran kepada responden akan karya film yang ditonton, terdapat 41\% responden yang menyatakan setuju dan sangat setuju bahwa rumah produksi tertentu memiliki karya yang dapat langsung memberikan gambaran kepada penonton akan film yang disaksikan. Misalnya saja seperti film yang diproduksi oleh Soraya Films yang identik dengan film bertema drama. Akan tetapi terdapat 29\% responden yang menyatakan ragu-ragu dan $30 \%$ yang menyatakan tidak setuju.

\section{Dimensi Sekuel}

Tabel 7

Pertanyaan dalam Dimensi Sekuel

\begin{tabular}{|c|c|c|c|c|c|}
\hline \multicolumn{1}{|c|}{ Item Pertanyaan } & SS & S & RR & TS & STS \\
\hline $\begin{array}{l}\text { Sekuel atau film lanjutan dari film } \\
\text { sebelumnya menentukan anda } \\
\text { dalam memilih film yang ditonton }\end{array}$ & $19,5 \%$ & $68 \%$ & $7,5 \%$ & $4,5 \%$ & $0,5 \%$ \\
\hline
\end{tabular}




\begin{tabular}{|l|l|l|l|l|l|}
\hline $\begin{array}{l}\text { Sekuel atau film lanjutan dari film } \\
\text { sebelumnya memberikan anda } \\
\text { gambaran akan film yang akan } \\
\text { ditonton }\end{array}$ & $17 \%$ & $71 \%$ & $10,5 \%$ & $0,5 \%$ & $1 \%$ \\
\hline $\begin{array}{l}\text { Sekuel film mempermudah dalam } \\
\text { memahami film yang ditonton }\end{array}$ & $18,5 \%$ & $64,5 \%$ & $12 \%$ & $4 \%$ & $1 \%$ \\
\hline
\end{tabular}

Berdasarkan tabel di atas, mayoritas responden menyatakan setuju dan sangat setuju yaitu sebesar $87,5 \%$ bahwa sekuel suatu film dapat menjadi penentu untuk memilih film yang akan ditonton. Akan tetapi terdapat $7.5 \%$ reponden yang menyatakan ragu-ragu dan 5\% responden menyatakan tidak setuju dan sangat tidak setuju. Sedangkan sekuel film dapat memberikan gambaran akan film yang ditonton, mayoritas responden menyatakan setuju, yaitu sebesar $88 \%$. Akan tetapi terdapat $10.5 \%$ reponden yang menyatakan ragu-ragu dan $1.5 \%$ responden menyatakan tidak setuju dan sangat setuju.

Responden juga menyatakan bahwa sekuel film membantu mereka dalam memahami film yang ditontonnya, yaitu sebesar $83 \%$. Akan tetapi terdapat $12 \%$ reponden yang menyatakan ragu-ragu dan $5 \%$ responden menyatakan tidak setuju dan tidak setuju.

\section{Dimensi Latar}

Tabel 8

Pertanyaan dalam Dimensi Latar

\begin{tabular}{|l|c|c|c|c|c|}
\hline \multicolumn{1}{|c|}{ Item Pertanyaan } & SS & S & RR & TS & STS \\
\hline $\begin{array}{l}\text { Latar atau lokasi pengambilan } \\
\text { gambar film menjadi unsur yang } \\
\text { menentukan dalam menonton } \\
\text { film }\end{array}$ & $15,5 \%$ & $54,5 \%$ & $17,5 \%$ & $11,5 \%$ & $1 \%$ \\
\hline $\begin{array}{l}\text { Latar film membuat anda } \\
\text { mudah untuk memahami film } \\
\text { yang ditonton }\end{array}$ & $12 \%$ & $55,5 \%$ & $18,5 \%$ & $11,5 \%$ & $2,5 \%$ \\
\hline $\begin{array}{l}\text { Latar film tertentu membuat } \\
\text { adanya kedekatan akan film } \\
\text { yang ditonton }\end{array}$ & $2,5 \%$ & $17,5 \%$ & $16 \%$ & $53,5 \%$ & $10,5 \%$ \\
\hline
\end{tabular}

Berdasarkan tabel di atas, mayoritas responden menyatakan setuju dan sangat setuju yaitu sebesar $70 \%$ bahwa latar atau lokasi pengambilan gambar suatu film dapat meningkatkan ekspektasi terhadap film yang akan disaksikan. Akan tetapi terdapat $17.5 \%$ reponden yang menyatakan ragu-ragu dan $12.5 \%$ responden menyatakan tidak setuju dan tidak setuju. Selain itu mayoritas responden juga menyatakan bahwa latar 
sebuah film dapat memberikan gambaran umum akan film yang responden saksikan. Akan tetapi terdapat $18.5 \%$ reponden yang menyatakan ragu-ragu dan $13.5 \%$ responden menyatakan tidak setuju dan sangat tidak setuju.

Latar atau lokasi pengambilan gambar sebuah film ternyata tidak dapat menimbulkan kedekatan antara responden dengan film yang ditontonnya. Misalnya film yang berlatar atau mengambil lokasi di Sumatra Barat seperti Film "Me Vs Mom"; dapat saja menimbulkan ikatan kedekatan pada orang-orang Minang yang menonton film tersebut. Mayoritas responden menyatakan tidak setuju dan sangat tidak setuju yaitu sebesar $64 \%$. Akan tetapi terdapat $16 \%$ yang menyatakan ragu-ragu dan $20 \%$ yang menyatakan tidak setuju.

\section{Dimensi Pemasaran}

Tabel 9

Pertanyaan dalam Dimensi Pemasaran

\begin{tabular}{|l|l|l|l|l|l|}
\hline Item Pertanyaan & SS & S & RR & TS & STS \\
\hline $\begin{array}{l}\text { Pemasaran film dengan poster, trailer, } \\
\text { publikasi lainnya memunculkan } \\
\text { ekspektasi lebih terhadap film yang } \\
\text { ditontonnya }\end{array}$ & $19 \%$ & $67 \%$ & $8 \%$ & $6 \%$ & $0 \%$ \\
\hline $\begin{array}{l}\text { Pemasaran film dengan poster, trailer, } \\
\text { publikasi lainnya membuat anda ingin } \\
\text { menonton film }\end{array}$ & $18 \%$ & $68 \%$ & $10,5 \%$ & $3,5 \%$ & $0 \%$ \\
\hline $\begin{array}{l}\text { Adanya poster, trailer, publikasi } \\
\text { lainnya mempermudah dalam } \\
\text { menentukan film yang akan ditonton }\end{array}$ & $19,5 \%$ & $65 \%$ & $10,5 \%$ & $5 \%$ & $0 \%$ \\
\hline
\end{tabular}

Berdasarkan tabel di atas, mayoritas responden menyatakan setuju dan sangat setuju bahwa pemasaran suatu film melalui trailer, poster, billboard, dan lain-lain dapat memunculkan atau meningkatkan ekspektasi kepada film yang responden saksikan. Akan tetapi terdapat 8\% reponden yang menyatakan ragu-ragu dan $6 \%$ responden menyatakan tidak setuju. Selain itu pemasaran film melalui trailer, poster, billboard, dan lain-lain dapat membuat responden ingin menonton film tertentu. Responden yang menjawab setuju dan sangat setuju sebesar $86 \%$. Akan tetapi terdapat $10.5 \%$ reponden yang menyatakan ragu-ragu dan 3.5\% responden menyatakan tidak setuju.

Mayoritas responden juga menyatakan setuju dan sangat setuju bahwa dengan adanya trailer, poster dan publikasi lainnya dapat mempermudah responden dalam menentukan film yang akan ditontonnya. Responden yang menjawab sebesar 84,5\%. Akan tetapi terdapat $10.5 \%$ reponden yang menyatakan ragu-ragu dan $5 \%$ responden menyatakan tidak setuju. 


\section{Analisis Rata-Rata per Dimensi}

Peneliti melakukan penghitungan rata-rata perdimensi untuk mencari dimensi dengan pilihan terbanyak dari responden. Adapun hasilnya sebagai berikut:

Tabel 10.

Rata-Rata Perdimensi

\begin{tabular}{lc}
\hline Jawaban & Mean \\
\hline Genre & 4.04 \\
\hline Karya Saduran & 3.92 \\
\hline Pemain & 3.67 \\
\hline Sutradara & 3.77 \\
\hline Rumah Produksi & 3.07 \\
\hline Sekuel & 3.98 \\
\hline Latar & 3.62 \\
\hline Pemasaran & 3.99 \\
\hline
\end{tabular}

Dari tabel di atas dapat diketahui bahwa preferensi penonton dalam menonton film Indonesia berdasarkan Genre sebagai alasan utama atau tertinggi dengan nilai rata-rata 4.04; diikuti oleh dimensi pemasaran dengan nilai rata-rata 3.99. Kemudian dimensi sekuel dengan nilai rata-rata 3.98 dan dilanjutkan dengan karya saduran dengan 3.92. Di urutan kelima dimensi sutradara dengan nilai rata-rata 3.77, lalu diikuti dimensi pemain dengan 3.67. Di urutan selanjutnya dimensi latar dengan nilai rata-rata desimal 3.62 dan dimensi rumah produksi dengan rata-rata 3.07 berada pada urutan terakhir.

Bila kita melihat preferensi penonton terhadap film Indonesia, tentunya berhubungan juga dengan media yang berlomba untuk merebut khalayak. Dalam konteks ini khalayak penonton secara aktif menentukan film Indonesia mana yang dipilih untuk ditontonnya, sehingga dapat dilihat seperti apa preferensi penonton terhadap film Indonesia. Dalam melihat preferensi penonton akan film Indonesia, dilihat dari atribut film yaitu genre, karya saduran, pemain, sutradara, sekuel, rumah produksi, latar dan pemasaran.

Dimensi genre menjadi faktor utama responden dalam menonton film Indonesia. Genre frama mendominasi film-film Indonesia, namun perfilman Indonesia juga sudah mulai mengeksplorasi genre lainnya seperti film "Battle of Surabaya" (2015) yang merupakan film bergenre animasi, serta genre eksperimental dengan tema bencana alam seperti film Bangkit! (2016). Genre film memberikan stimulasi kepada penonton dalam memenuhi kepuasan di dalam dirinya. Responden setuju bahwa dengan melihat Genre film maka menjadi penentu dalam menonton film Indonesia.

Preferensi penonton yang kedua adalah dimensi pemasaran. Hal ini karena Pemasaran mampu menjadi sarana informasi dan pemahaman responden dalam menonton film Indonesia. Pemasaran dalam film merupakan pemasaran dalam bentuk audio, visual, dan 
audio-visual, yaitu poster, papan reklame, trailer, iklan di televisi, spot radio, adlibs radio, iklan di media sosial, review blog atau website, press release, screening perdana film, dan lain-lain. Iklan di media sosial saat ini menjadi cara efektif untuk memasarkan film karena memiliki dampak yang besar dan jangkauan luas dengan modal yang rendah. Hal ini berhubungan dengan kebiasaan masyarakat yang mulai terbiasa menggunakan internet sebagai media pencarian informasi. Dengan begitu penonton mengetahui kapan film tayang, berjudul apa, bercerita tentang apa, siapa yang akan main, siapa yang mengarahkan pemain, dan lain-lain terhadap film Indonesia.

Preferensi penonton selanjutnya adalah dimensi sekuel. Dapat disimpulkan bahwa alasan lain responden menonton film Indonesia adalah adanya pengaruh sekuel dalam film. Hal ini karena Sekuel film memberikan rasa kedekatan kepada penonton sehingga dapat menghindari, mengurangi, dan mencegah kemungkinan terjadinya ketidakpuasan dalam menonton film Indonesia. Sekuel dapat penonton saksikan ketika tayangnya film lanjutan atau kedua setelah film pertama, contohnya seperti film AADC 2 yang tayang di bioskop.

Preferensi penonton berdasarkan karya saduran berada pada urutan keempat. Hal ini menandakan bahwa selain memberikan hiburan dan informasi, karya saduran dapat meyakinkan penonton bahwa film yang diadaptasi dari karya saduran dapat memberikan hiburan dan melepaskan ketegangan penonton terhadap film Indonesia. Karya saduran merupakan karya lain atau karya yang berhubungan dengan karya sebelumnya, contohnya seperti film "Marmut Merah Jambu" yang merupakan film yang diadaptasi dari Novel hasil karya Raditya Dika.

Preferesi penonton berikutnya adalah Sutradara. Sutradara seperti Mira Lesmana, Joko Anwar, Riri Rheza, dan lain-lain dapat mempengaruhi preferensi penonton dalam menonton film Indonesia. Hal ini karena setiap Sutradara memiliki status pribadi dan kredibilitas dalam pembuatan film. Dengan begitu penonton memperoleh rasa percaya dan pemahaman bahwa film Indonesia hasil karya dari sutradara tertentu dapat memenuhi kepuasan di dalam dirinya.

Unsur pemain seperti Iko Uwais, Dian Sastro, Raditya Dika, dan lain-lain memiliki pengaruh dalam preferensi penonton film Indonesia. Sama halnya seperti sutradara, pemain memiliki status dan kredibilitas tersendiri di mata masyarakat. Responden setuju bahwa mereka menonton film Indonesia yang di dalamnya terdapat seorang pemain tertentu. Hal ini karena pemain mampu mengalihkan sesuatu yang tidak memuaskan penonton dalam film Indonesia.

Dimensi latar film menduduki peringkat ketujuh dalam preferensi penonton terhadap film Indonesia. Hal ini menandakan bahwa Latar mampu menjadi sarana pengalihan ketegangan dan hiburan bagi penonton melalui gambar dan lokasi cerita yang menghibur bagi penonton melalui gambar dan lokasi cerita yang menghibur seperti di Paris, Beijing, 
Belanda, dan lain-lain. Latar sendiri saat ini sudah mulai di perhatikan oleh perfilman Indonesia, namun latar yang digunakan oleh beberapa film belum mencerminkan lokasi Indonesia sendiri seperti "Winter in Tokyo" (2016) yang berlokasi di Tokyo, Jepang. Pilihan terakhir penonton adalah dimensi rumah produksi. Hal ini menandakan rumah produksi memiliki pengaruh kecil dalam pemenuhan kebutuhan penonton akan dengan film yang disajikan.

\section{SIMPULAN}

Dari hasil penelitian yang dilakukan maka dapat ditarik simpulan bahwa preferensi penonton terhadap film Indonesia berdasarkan atribut film diawali dari genre sebagai pilihan kesukaan mereka dalam menonton. Dilanjutkan dengan pemasaran seperti sinopsis atau trailer film, karena sebelum menonton mereka cenderung mencari informasi terhadap film yang akan disaksikan. Setelah memilih genre dan mendapatkan informasi dari pemasaran, penonton akan mengutamakan film yang memiliki sekuel dibandingkan dengan film baru. Jika tidak terdapat film sekuel, penonton cenderung akan memilih film karya saduran, manakala film ini merupakan film yang disadur dari karya lainnya. Lalu penonton akan menentukan film berdasarkan sutradaranya, karena setiap sutradara memiliki kredibilitasnya dalam membuat film. Adapun penonton yang menentukan film berdasarkan pemain kesukaannya. Saat ini latar film sudah mulai diperhatikan oleh penonton, namun latar film berada di urutan ketujuh karena atribut ini cenderung bisa diketahui melalui judul film atau pemasaran. Atribut rumah produksi menjadi preferensi terakhir karena penonton cenderung belum memahami peran rumah produksi dalam sebuah film.

Agar kecintaan masyarakat akan film Indonesia lebih ditingkatkan, maka diharapkan bagi insan perfilman dapat lebih mengeksplorasi penentuan genre film sehingga dapat terciptanya keberagaman dan peningkatan kualitas film Indonesia. Selain itu mengoptimalkan penggunaan media internet dan media sosial sebagai sarana pemasaran agar lebih memudahkan sineas dalam menggapai penontonnya. Selain itu disarankan untuk dapat lebih mengangkat dan menjelajah lokasi film yang berada di Indonesia melalui adanya kerjasama dengan pemerintah, badan institusi yang mendukung pengembangan budaya atau pariwisata Indonesia. Dengan begitu perfilman Indonesia bisa lebih menunjukkan identitas perfilmannya dengan memperkenalkan keindahan Indonesia kepada masyarakat domestik dan mancanegara, serta dapat memberikan dampak kepada sektor pengembangan lainnya seperti sektor pariwisata atau budaya. 


\section{DAFTAR PUSTAKA}

Awaluddin, I. (2012, Maret 30). Blog. Retrieved from Bincangmedia.wordpress.com: https://bincangmedia.wordpress.com/2012/03/30/dinamika-industriperfilman-indonesia-dari-gambar-idoep-ke-cineplex/

Data Penonton. (2014). Retrieved from filmindonesia.or.id: http://filmindonesia.or.id/movie/viewer/2014\#.Vn951Wxukkk

Data Penonton. (2015). Retrieved from Filmindonesia.or.id: http://filmindonesia.or.id/movie/viewer\#.Vnz-xWxuka1

Frampton, H. (2009). Love For The Cinema Makes Me Sad. In L. During, \& D. Levitt, Film Theory (p. 267). USA: Oxford University Press.

Gazley, A., Clark, G., \& Sinha, A. (2011). Understanding preferences for motion pictures. Journal of Business Research 64, 854-861.

Klavert, D. R. (2013). Perbedaan Preferensi Konsumen Terhadap Atribut Film. Perbedaan Preferensi Konsumen Terhadap Atribut Film, 1-13.

Kotler, P., \& Amstrong, G. (2003). Dasar-dasar Pemasaran. PT INDEKS Kelompok Gramedia.

Kurniawati, I. (2006). Prefensi Pembaca Terhadap Rubrik Surat Kabar Jawa Pos (Studi pada Pembaca Jawa Pos di Malang Melalui Metode Item Selection dan Tracking Study). Preferensi Pembaca Terhadap Rubrik Surat Kabar Jawa Pos, 1-2.

McQuail. (2011). Teori Komunikasi Massa Buku 1. Jakarta: Salemba humanika.

McQuail. (2011). Teori Komunikasi Massa Buku 2. Jakarta: Salemba Humanika.

Pratista, H. (2008). Memahami Film. Yogyakarta: Homerian Pustaka.

Rabiger, M. (2008). Directing Film Techniques and Aesthetics. USA: Elsevier.

Rulianto, A. (2015, Agustus 3). Artikel Film. Retrieved from Muvila.com: http://www.muvila.com/film/artikel/jumlah-penonton-turun-akibat-film-tidakbermutu-150803h.html

Sugiyono. (2009). Metode Penelitian Kuantitatif Kualitatif dan R\&D. Bandung: ALFABETA.

Trianton, T. (2013). Film Sebagai Media Pelajaran. Yogyakarta: Graha Ilmu. 